\title{
Colloidal and Thermal Behaviors of Some Venezuelan Kaolin Pastes for Therapeutic Applications
}

\author{
Ana C. Hernández ${ }^{1,2}$, Mahmoud E. Awad ${ }^{3,4,5}$, Williams Meléndez ${ }^{6}$, Gema González ${ }^{2,7}$, \\ Alberto López-Galindo ${ }^{4, *}$, Rita Sánchez-Espejo ${ }^{5}$, Fátima García-Villén ${ }^{5}$ (i) and César Viseras ${ }^{4,5}$ \\ 1 Instituto Universitario de Xeoloxía, Universidade da Coruña, 15071 A Coruña, Spain; \\ hernandezsantome@gmail.com \\ 2 Laboratorio de Materiales, Centro de Ingeniería de Materiales y Nanotecnología, Instituto Venezolano de \\ Investigaciones Científicas (IVIC), Apartado 20632, Caracas 1020, Venezuela; gemagonz@gmail.com \\ 3 Department of Geology, Faculty of Science, Al Azhar University in Cairo, Cairo 11884, Egypt; \\ mawad@azhar.edu.eg \\ 4 Andalusian Institute of Earth Sciences (Consejo Superior de Investigaciones Científicas-University of \\ Granada), Armilla, 18100 Granada, Spain; cviseras@ugr.es \\ 5 Department of Pharmacy and Pharmaceutical Technology, University of Granada, 18071 Granada, Spain; \\ ritaespejo@hotmail.com (R.S.-E.); fgarvillen@ugr.es (F.G.-V.) \\ 6 Instituto de Ciencias de la Tierra, Facultad de Ciencias, Universidad Central de Venezuela, \\ Caracas 1050, Venezuela; wmelende.08@gmail.com \\ 7 School of Physical Sciences and Nanotechnology, Yachay Tech University, Urcuqui EC170505, Ecuador \\ * Correspondence: alberto@ugr.es
}

Received: 4 November 2019; Accepted: 29 November 2019; Published: 4 December 2019

\begin{abstract}
This work contributes to the knowledge of colloidal and thermal properties of some important primary-originated kaolin deposits from Bolivar State, Venezuela, and their possible use as semisolid formulations in medicinal muds for topical applications. Eight selected high purity kaolin samples were characterized. Rheological and thermal properties were correlated to physico-chemical characteristics of the clay suspensions $\left(\mathrm{pH}, \mathrm{Ca}^{2+}\right.$, and $\mathrm{Mg}^{2+}$ cation desorption and surface charge). Most of the studied kaolin pastes showed adequate viscosities, acceptable skin safe $\mathrm{pH}$, and good thermal properties for pelotherapeutic uses. Three of the studied samples, in particular, showed very high kaolinite purities ( $>92 \%$ kaolinite), elevated viscosities (>1 Pa.s), and good thermal and $\mathrm{pH}$ performances for topical application.
\end{abstract}

Keywords: kaolin; mud therapy; thermal properties; zeta potential; rheology

\section{Introduction}

Clay minerals have been widely used to develop products and functionalities in a large variety of areas, including materials, pharmaceuticals, food sciences, and biotechnology. Mixtures of clays and mineral waters are used in health mud therapies, either for thermotherapeutic or cosmetic purposes, and constitute the basis of most of the muds used in healing and spa centers. The ever-increasing use of clay minerals in pelotherapeutic applications is due to the versatility and peculiarity of their physical and chemical properties and the suitability of their colloidal and thermal behaviors [1-15]. Pioneer studies $[16,17]$ indicated that rheology is mainly controlled by the morphology and aggregation state of solid particles, as well as the nature and strength of the predominant interparticle electrostatic forces (i.e., as predicted by zeta potential measurements), which are fundamental parameters to qualify the properties of clayey dispersions, such as spreading qualities, adhesion to skin and removal capacities [16,18-22], and these are affected by $\mathrm{pH}$, concentration, and relative dimensions of solids [23]. 
On the other hand, clay thermal behaviors (cooling kinetics and heat capacity) are directly responsible for their therapeutic effect [3,5,24-26].

Kaolinite is the main clay mineral of the kaolin group, and it has attracted great interest in pharmaceutics and therapy fields based on their properties [27]. Technologically, the optimal water content for the formulation of consistent and adequate adhesive kaolinite pastes is a 1:1 (w/w) solid/liquid ratio of the prepared aqueous dispersions [28]. In addition to the influence of water content and solid fraction composition in the quality and healing activity of the thermotherapeutic muds, Awad et al. [29] proved that the thermal efficiency and performance of therapeutic kaolin pastes (heat retention capacity and prolonged release) are controlled by the granulometric properties of kaolin powder (i.e., including the particle size, grading, surface area, and particle textural packing), and the degree of structural order-disorder and crystallite size of the kaolinite. As the appropriate uniformity grading and particle fineness of the kaolin powder were found to be controlled by the mineral's structural characteristics, the later ones correlate directly with its composition and chemical variability [30].

Concerning economically viable Venezuelan kaolin resources, Hernández et al. [31] characterized their compositional, structural, and textural characteristics in order to evaluate their suitability as health care components. On the basis of these results, the aim of the present work is to determine the colloidal and thermal properties of representative high-grade Venezuelan kaolin samples to evaluate their possible use as semisolid formulations in medicinal peloids.

\section{Materials and Methods}

\subsection{Materials and Paste Formulation}

Eight representative high-grade kaolin samples (collected from different primary kaolin deposits on the Guayana shield, in Bolivar State, Venezuela), namely VE1, VE2, VE3, VE4, VE5, VE6, VE9, and VE12, were selected for the present study. Their geological context and mineralogical compositions were described in Hernández et al. [31]. Each sample was dried, pulverized, and sieved to obtain particle aggregates below $125 \mu \mathrm{m}$. Kaolinite pastes 1:1 $(w / w)$ were prepared with purified water (at $25^{\circ} \mathrm{C}$ ambient temperature) using a vortex mixer and then kept moist in a refrigerator prior to the targeted characterizations.

\section{2. $\mathrm{pH}$ Measurement}

The $\mathrm{pH}$ of the aqueous suspensions of kaolin was measured under mechanical agitation using a Crison pH-meter Basic 20+ equipped with a semisolid sensor (5053 T) calibrated by standard solutions at $\mathrm{pH} 4,7$, and 9. The $\mathrm{pH}$ tolerance ranges between 2 and 11 . Three replicates were carried out for each measurement and results averaged ( \pm 0.1 standard deviation).

\subsection{Apparent Viscosity Measurement}

Rheological analysis was carried out by a computerized controlled rate viscometer (RotoVisco 1; HAAKE RheoWin software, Thermo Scientific HAAKE, Waltham, MA, USA) as a triple measure of apparent viscosity ( $\eta$ in Pa.s) at a controlled temperature $\left(25^{\circ} \mathrm{C}\right)$ after a rest time of $90 \mathrm{~s}$ in the shear rate range 10-800 s${ }^{-1}$. Before treatment, samples were sonicated for $3 \mathrm{~min}$ using Power Sonic 405 ultrasonic equipment (Hwashin, Tech Co. Ltd., Gangnam-gu, Seoul, Korea). Four replicates were performed for each sample.

\subsection{Zeta Potential Measurement}

Zeta potential measurements were performed using an electrophoretic light scattering (ELS) Zetasizer Naso- $Z^{\mathrm{TM}}$ (Malvern Instruments, Malvern, UK). The measurements were taken through a downward ramp from $\mathrm{pH} 3$ to $\mathrm{pH}$ 9. The resultant suspensions $(10 \mathrm{mg}$ of powder sonicated in $100 \mathrm{~mL}$ of deionized water) were introduced into folded $1 \mathrm{~mL}$ capacity capillary zeta potential cells (DTS1061, Malvern Instruments). Measurements were taken at a temperature of $25 \pm 0.1{ }^{\circ} \mathrm{C}$, and three replicates 
were obtained for each sample. The zeta potentials and iso-electric points at each corresponding $\mathrm{pH}$ condition were performed using Smoluchowski's equation [32].

\subsection{Desorbed Cation Measurements}

Experimental cation desorption was performed following the same method described in Sánchez-Espejo [15]. The aqueous supernatant phases were separated from the solid mud by centrifugation and filtration through a membrane filter with a $0.05 \mu \mathrm{m}$ pore size. $\mathrm{Ca}^{2+}$ and $\mathrm{Mg}^{2+}$ cations in the filtrates were then analyzed by means of ICP-OES technique.

\subsection{Thermal Measurements}

Specific heat was determined by means of a differential scanning calorimetry (DSC) technique using a Shimatzu ${ }^{\circledR}$ DSC-50 Calorimeter (Shimadzu Corporation, Nakagyo Ward, Kyoto, Japan). Samples were introduced in a closed $50 \mathrm{~mL}$ cylindrical Teflon container and heated at constant temperature $\left(70{ }^{\circ} \mathrm{C}\right)$ and immersed in a thermostatic bath (Edelstahl Rostfrei $\left.{ }^{\circledR}\right)$ at $35^{\circ} \mathrm{C}$. The temperature was measured every $30 \mathrm{~s}$ by a Dual Thermometer LT Lutron TM-906A until the temperatures of the kaolin paste sample and the thermostatic bath were equal. Cooling curves were optimized following the procedure described by Sánchez-Espejo et al. [15], where cooling kinetics were calculated following Cara et al. [3]. Experimental cooling data were fitted using Newton's Law, describing the thermal exchange between two bodies in contact at different temperatures:

$$
\left(T-T_{\min }\right)=\left(T_{\max }-T_{\min }\right) e^{-K t}
$$

where, $T_{\min }$ was the room temperature $\left(25^{\circ} \mathrm{C}\right), T_{\max }$ was the initial temperature $\left(50^{\circ} \mathrm{C}\right), t$ was the time in minutes, and $K$ was the constant that depends on the material and apparatus, given by:

$$
K=\frac{\mathrm{P}}{\mathrm{C}}=\frac{\mathrm{P}}{m C_{p}}
$$

where, $\mathrm{P}$ is the instrumental constant of the apparatus, $C$ the heat capacity of the heated material, $m$ the heated mass, and $C_{p}$ the specific heat. Experimental thermal parameters of the studied samples were then obtained using the aforementioned equations.

\section{Results and Discussion}

\subsection{Mineralogy}

Table 1 summarizes the mineral composition and Hinckley Index (HI) of the studied samples, determined by X-ray diffraction and chemical analysis [31]. Samples essentially consisted of kaolinite, with contents ranging from $73 \%$ to $99 \%$, with an average of $88.3 \%$. Other detected minerals included quartz, gibbsite, hematite, anatase, rutile, and mica as impurities. According to the HI, kaolinite in all samples had a basically ordered structure $(\mathrm{HI}>0.7)$. Contents of trace elements in the global kaolin deposits were attributed to their substitutions in the crystal structures of the associated titanium oxides and iron oxy-hydroxide minerals. Hence, the $\mathrm{Pb}$ and $\mathrm{As}(\mathrm{ppm})$ contents can be easily reduced to safe limits by removal of these impurities following reported kaolin purification methods [27]. 
Table 1. Kaolinite contents, degree of structural order-disorder (HI), mineral impurities, iron oxide contents, and desorbed cations in the formulated kaolin samples.

\begin{tabular}{ccccccc}
\hline Samples & $\begin{array}{c}\text { Kaolinite } \\
(\%)\end{array}$ & HI & $\begin{array}{c}\text { Associated Mineral } \\
\text { Impurities }\end{array}$ & $\mathbf{F e}_{2} \mathbf{O}_{3}$ (\%) & \multicolumn{2}{c}{ Desorbed Cations (mg/L) } \\
\cline { 6 - 7 } VE1 & 75 & 1.2 & $\begin{array}{c}\text { Gibbsite (20\%), Fe-Ti oxide } \\
\text { minerals (4\%), quartz (1\%) }\end{array}$ & 1.79 & 29.8 & 8.59 \\
\hline VE2 & 92 & 0.7 & $\begin{array}{c}\text { Gibbsite (4\%), Fe-Ti oxide } \\
\text { minerals (3\%), quartz (1\%) }\end{array}$ & 0.70 & 70.57 & 75.08 \\
\hline VE3 & 94 & 1.3 & Gibbsite (5\%), anatase (1\%) & 0.34 & 26.33 & 46.92 \\
\hline VE4 & 99 & 1.2 & Gibbsite (1\%). & 0.37 & 0.77 & - \\
\hline VE5 & 88 & 1.4 & $\begin{array}{c}\text { Mica (5\%), quartz (6\%), } \\
\text { anatase (1\%) }\end{array}$ & 0.37 & - & - \\
\hline VE6 & 92 & 1.4 & $\begin{array}{c}\text { Gibbsite (5\%), Fe-Ti oxide } \\
\text { minerals (2\%), quartz (1\%) }\end{array}$ & 2.06 & 4.61 & - \\
\hline VE9 & 94 & 0.9 & $\begin{array}{c}\text { Quartz (4\%), Fe-Ti oxide } \\
\text { minerals (2\%) }\end{array}$ & 0.81 & - & 47.08 \\
\hline VE12 & 73 & 0.9 & $\begin{array}{c}\text { Gibbsite (13\%), quartz (3\%), } \\
\text { zircon (2\%), }\end{array}$ \\
\hline
\end{tabular}

\subsection{Rheology}

Table 2 summarizes the apparent viscosity of the studied water-based kaolin pastes, calculated at a shear value of $250 \mathrm{~s}^{-1}$, at $25^{\circ} \mathrm{C}$, which is representative of the stress produced by skin spreading during applications [33]. The aqueous dispersions of kaolin showed typical non-Newtonian viscoplastic flow curves with variable behavior. VE9 showed the highest average apparent viscosity (3.96 Pa.s), while VE1, VE3, VE4, and VE6 also showed high apparent viscosity (>1 Pa.s). Possibly as a result of the significant iron oxide contents $(7.76 \%)$, the dispersions formulated with VE12 showed negligible apparent viscosity (0.03 Pa.s), which would prevent the permanence of the product during application. In general, the viscosities measured in these Venezuelan kaolins are high in comparison to other kaolins [34-37]. Studies on other types of clay used for pelotherapy (bentonites) showed viscosities higher than $1 \mathrm{~Pa} \cdot \mathrm{s}[38,39]$. Thus, the higher values of viscosity in the kaolin suspensions would facilitate management and permanence on the application area of the skin, whereas lower values tend to have inadequate consistency $[2,10,40]$. Therefore, dispersions formulated with VE6 and VE9 had the best potential to form clay pastes with rheological behavior adequate for treatments.

Table 2. Viscosity (at $250 \mathrm{~s}^{-1}, 25^{\circ} \mathrm{C}$ ), $\mathrm{pH}$ values, and the median size $\left(\mathrm{D}_{50}\right)$ of the studied kaolin dispersions.

\begin{tabular}{ccccc}
\hline Samples & Flow Character & Viscosity $($ Pa.s) \pm S.D. $(\boldsymbol{n}=\mathbf{4})$ & Suspension $\mathbf{p H} \pm$ S.D. $(\boldsymbol{n}=\mathbf{3})$ & $\mathbf{D}_{\mathbf{5 0}}(\boldsymbol{\mu m})$ \\
\hline VE1 & Pseudoplastic & $1.82 \pm 0.10$ & $4.30 \pm 0.01$ & 1.05 \\
VE2 & Dilatant & $0.70 \pm 0.05$ & $4.50 \pm 0.02$ & 1.12 \\
VE3 & Dilatant & $1.13 \pm 0.30$ & $4.40 \pm 0.07$ & 1.24 \\
VE4 & Dilatant & $1.44 \pm 0.20$ & $4.52 \pm 0.09$ & 1.55 \\
VE5 & Dilatant & $0.32 \pm 0.10$ & $4.50 \pm 0.04$ & 2.29 \\
VE6 & Dilatant & $2.98 \pm 0.20$ & $4.70 \pm 0.05$ & 5.1 \\
VE9 & Pseudoplastic & $3.96 \pm 0.20$ & $5.90 \pm 0.12$ & 1.81 \\
VE12 & Dilatant & $0.03 \pm 0.10$ & $3.86 \pm 0.89$ & 1.83 \\
\hline
\end{tabular}

The rheological behavior of kaolin suspensions is governed by size, morphology, aggregation, and surface charge in the clay mineral particles $[16,17]$. Favorable rheological behaviors are expected with a combination of coarse, medium, and fine grains because interferences are minimized due to the reduction of the free space between the rotation spheres of bigger particles [41]. The studied kaolins exhibited highly variable granulometric D50 and D90 values (from approximately 1 to $5 \mu \mathrm{m}$ and 4 to 
$52 \mu \mathrm{m}$, respectively, [31]). Moreover, samples VE1, VE3, VE4, VE6, and VE9, with > 1 Paviscosities, present at least two groups with different kaolinite particle sizes [31]. On the other hand, the presence of specific impurities modified the resultant viscosity. VE12, with the highest amount of impurities (Table 1), exhibited the lowest viscosity values (Table 2). The presence of mica reduced the viscosity in VE5, whereas the presence of gibbsite [42] increased the viscosities and produced shear thickening flows in those samples with noticeable amounts of this mineral.

\section{3. $p H$}

Table 2 also summarizes the $\mathrm{pH}$ values of the studied kaolins dispersed in purified water. The samples were acid in character, with $\mathrm{pH}$ ranges from 3.86 to 5.97. The pure Fe-Ti oxide minerals and gibbsite were stable at $\mathrm{pH}>5$, while they could be dissociated under $\mathrm{pH}<5$ conditions. However, the highest $\mathrm{Ca}^{2+}$ content $(155.80 \mathrm{mg} / \mathrm{L})$ found in sample VE12, with its variable mineralogical composition, probably had the most influence on the ionic strength of the kaolin primary colloidal solutions and hence on the measured aqueous dispersions, which could maintain stabilities of the associated gibbsite and Fe-Ti oxide mineral phases till $\mathrm{pH} \approx 4$. The $\mathrm{pH}$ values of the dispersions prepared with samples VE2, VE3, VE5, VE6, and VE9 could permit topical application in terms of the $\mathrm{pH}$ tolerability range of the human skin (4.5-6). Specifically, the pH of VE6 was closer to the most healthy human skin $\mathrm{pH}$ (approximately 4.7), which is favorable to skin microflora [43] and prevents the growth of pathogenic bacteria [44]. It has been reported that $\mathrm{Al}(\mathrm{OH})_{3}$ (gibbsite) is insoluble at $\mathrm{pH} 5$ to 8, but the dissolution of $\mathrm{Al}$ increases under more acid conditions [45]. However, clinical trials showed that the aluminum compounds, as used in cosmetic products, are dermatologically safe, as they have no toxic effects and do not irritate the skin [46,47]. Moreover, the acidic character of the studied kaolin-based pastes can be optimized with pharmaceutical $\mathrm{pH}$ buffer mediators.

\subsection{Zeta Potential}

Figure 1 shows the zeta potential (ZP) of the studied kaolins at their corresponding $\mathrm{pH}$ values. The measured ZP profiles were mainly steady and oscillated slightly around $-5 \mathrm{mV}$ within the $\mathrm{pH}$ 3-9 range. ZP values were negative due to the permanent negative charges on the kaolinite particle surfaces, and the highest variability of zeta potential was observed at $\mathrm{pH}$ 5-7. A slightly decreasing trend in $\mathrm{ZP}$ can be observed with increasing $\mathrm{pH}$ in most of the samples, probably due to the increase of hydroxyl groups caused by the hydrolysis of water molecules. According to Williams and Williams [32], the increase in acidity causes the zeta potential to become less negative and even reach positive values at low $\mathrm{pH}$. The resulting $\mathrm{ZP}$ values are noticeably low when compared with other studied kaolins [48-51]. This behavior could be related to the natural acidity of the studied kaolin aqueous suspensions, to the tendency of these kaolin samples to flocculate, and to the high viscosities measured in the samples. In fact, some authors have demonstrated a relation between zeta potential and the rheological properties of different mud-packs [52]. On the other hand, the presence of gibbsite normally implies positive surface charges in the $\mathrm{pH}$ range between 4 and 11 [53], and possibly affecting the magnitude of the zeta potential negativity.

Only sample VE3 showed an iso-electric point (IEP) value at $\mathrm{pH} \approx 6$, while no IEPs were observed in the other samples studied (Figure 1). The IEP of kaolinite suspensions has been reported at different $\mathrm{pH}[52,54,55]$. Yukselen and Kaya [56] also found showed a wide range of IEP for kaolinites, from absence to $\mathrm{pH}$ 6, and explained this variability as a result of kaolin composition.

Kaolinite commonly exhibits $\mathrm{pH}$-dependent zeta potential due to the positively charged aluminol surface of the octahedral sheet and the edge surface sites. However, in some reported cases, it may show a largely $\mathrm{pH}$-independent surface charge, suggesting cation substitution in the clay structure when exchangeable $\mathrm{Al}^{3+}$ releases under acidic conditions. This structural cation substitution leads to strong acid sites, where the surface charge is balanced by positive cations $\left(\mathrm{Ca}^{2+}, \mathrm{Mg}^{2+}, \mathrm{K}^{+}\right.$, and $\left.\mathrm{Na}^{+}\right)$ as counterions, thus explaining the slightly stable zeta potential in the $3-9 \mathrm{pH}$ range [57] (Figure 1). 


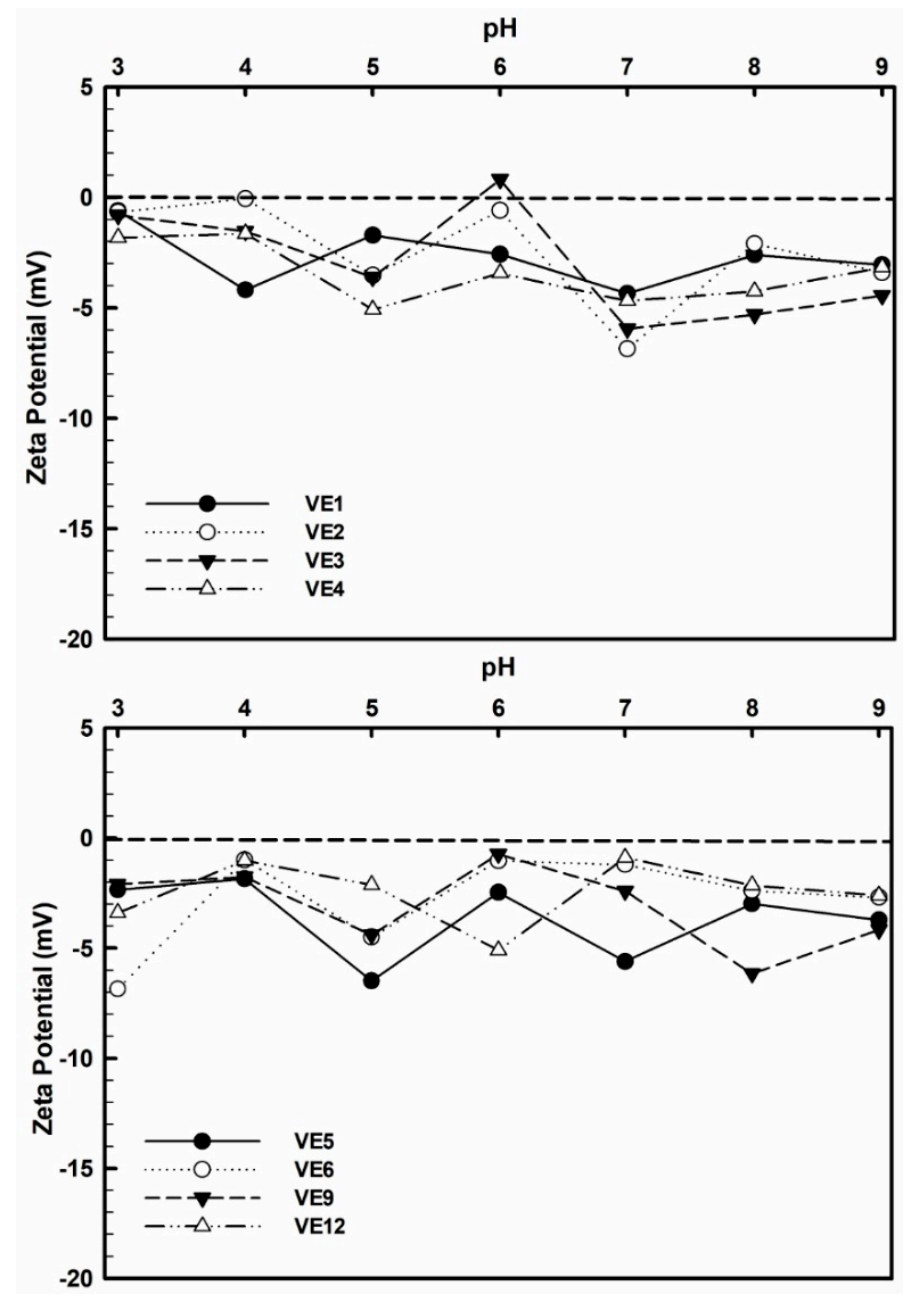

Figure 1. Zeta potentials of the studied kaolin samples with the corresponding $\mathrm{pH}$, at $25^{\circ} \mathrm{C}$.

\subsection{Desorbed Cations}

Table 1 shows the contents of the kaolinite-adsorbed $\mathrm{Ca}^{2+}$ and $\mathrm{Mg}^{2+}$ ions released in the supernatant aqueous phases. According to Yukselen and Kaya [56], the ZP of kaolinite becomes less negative with increasing $\mathrm{Ca}^{2+}$ and $\mathrm{Mg}^{2+}$ concentrations in the dispersion system. Samples VE12 and VE2, which exhibited the highest values of desorbed cations, also showed the highest $\mathrm{ZP}$ of most of the $\mathrm{pH}$ values analyzed.

Normally, kaolinite does not show interlayer cation exchange. However, during primary crystallization under natural acidic conditions, strong acid sites on the edge, and broken-bond surfaces arose due to structural cation substitution, accompanied by alteration of the net proton surface charge density, leading to an increase in the affinity of cation adsorption $\left(\mathrm{Ca}^{2+}\right.$ and $\left.\mathrm{Mg}^{2+}\right)$ onto the kaolinite surfaces $[57,58]$.

We were able to correlate the calculated crystallinity of kaolinite in the studied samples with the amounts of desorbed $\mathrm{Ca}^{2+}$ and $\mathrm{Mg}^{2+}$ in those samples with measurable cations (Figure 2). This is probably because disordered kaolinites and those with lower $\mathrm{HI}$ values have more layer stacking defects and broken edges across the basal surfaces, which can provide additional sites for the adsorption of the divalent $\mathrm{Ca}^{2+}$ and $\mathrm{Mg}^{2+}$ cations $[30,52,55]$. 


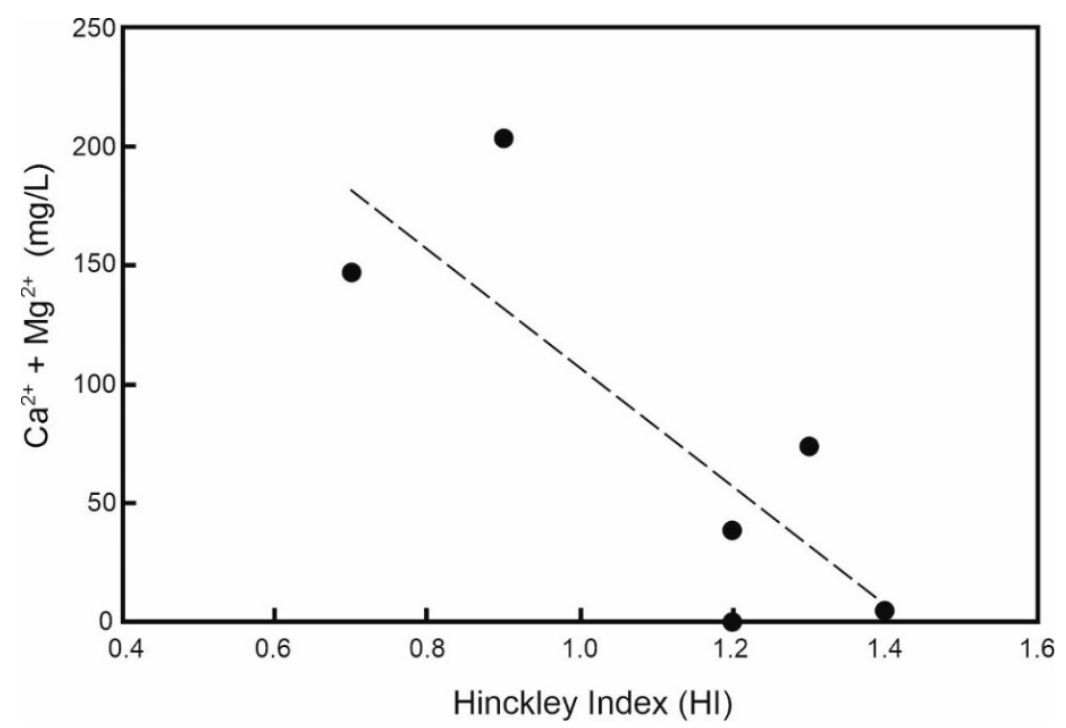

Figure 2. Calcium + magnesium concentrations versus Hinckley Index of the studied kaolinite samples.

\subsection{Thermal Characteristics}

Table 3 summarized the kinetic cooling parameters of the studied paste samples, including both theoretical and experimental specific heat values $(\mathrm{Cp})$, the heat retention time required to reach $32{ }^{\circ} \mathrm{C}$ $\left(\mathrm{t}_{32}\right)$ and the mud temperature after $20 \mathrm{~min}\left(\mathrm{~T}_{20}{ }^{\circ} \mathrm{C}\right)$, corresponding to the typical minimum application time of mud-packs, calculated by linear regression of Equation ( 1$)\left(R^{2}=0.9999\right.$ in all cases). Specific heat ranged from 2.42 to $3.00 \mathrm{~J} / \mathrm{K} \cdot \mathrm{g}$. In general, all samples showed specific heat values similar to those of some common clays evaluated for pelotherapy uses [40,59]. According to Awad et al. [29], the differences between theoretically calculated $\mathrm{Cp}$ values and the experimental values are normally attributed to small differences in the compositional variability at a fixed water content (50\%) used in all the formulated pastes. In Egyptian sedimentary kaolins, they also found that the specific heat and the heat retention time of kaolin pastes were mainly controlled by the powder granulometric properties. The specific heat capacity $\left(C_{p}\right)$ and heat retention time $\left(t_{32}\right)$ of those kaolin pastes were correlated negatively with kaolinite crystallite size, which in turn was a function of both the degree of kaolinite order-disorder and its chemical variability [30]. In the Venezuelan kaolin pastes examined here, on the contrary, the degree of kaolinite order-disorder (calculated as HI) was found to correlate positively with the experimental specific heat values of the kaolin paste samples (Figure 3), and, therefore, the heterogeneous microtextural characteristics and the non-uniformity of the particle grading found in these kaolins produced a closed packing arrangement, which must be the predominant effective factor in their thermal behavior.

Table 3. Kinetic cooling parameters of the studied kaolin paste samples (Theor.: theoretical; Exp.: experimental).

\begin{tabular}{ccccccc}
\hline \multirow{2}{*}{ Sample } & \multicolumn{2}{c}{$\mathbf{C}_{\mathbf{p}}(\mathbf{J} / \mathbf{K} \cdot \mathbf{g})$} & \multicolumn{2}{c}{$\boldsymbol{t}_{\mathbf{3 2}}{ }^{\circ} \mathbf{C}(\mathbf{m i n})$} & \multicolumn{2}{c}{$\mathbf{T}_{\mathbf{2 0}} \mathbf{m i n}\left({ }^{\circ} \mathbf{C}\right)$} \\
\cline { 2 - 7 } & Theor. & Exp. & Theor. & Exp. & Theor. & Exp. \\
\hline VE1 & 2.49 & 2.64 & 25.4 & 24.3 & 34.2 & 34.1 \\
VE2 & 2.55 & 2.42 & 24.1 & 23.6 & 33.7 & 33.7 \\
VE3 & 2.55 & 2.75 & 24.1 & 23.7 & 33.7 & 33.7 \\
VE4 & 2.56 & 2.61 & 23.5 & 23.0 & 33.4 & 33.4 \\
VE5 & 2.55 & 2.97 & 27.4 & 25.9 & 34.8 & 34.8 \\
VE6 & 2.54 & 3.00 & 26.5 & 26.1 & 34.7 & 34.7 \\
VE9 & 2.55 & 2.62 & 27.0 & 26.2 & 34.8 & 34.8 \\
VE12 & 2.47 & 2.78 & 27.0 & 26.1 & 35.0 & 35.0 \\
\hline
\end{tabular}




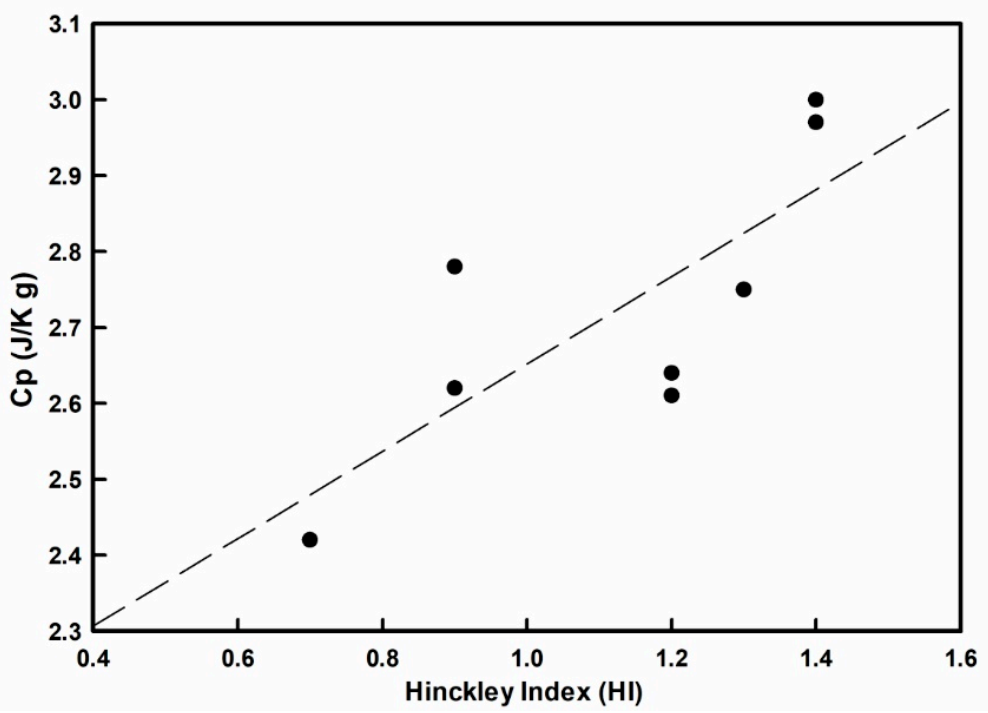

Figure 3. Experimental specific heat capacity versus Hinckley Index.

Heat retention time (cooling from 50 to $32{ }^{\circ} \mathrm{C}$ ) was found to be 23.5 to $27.4 \mathrm{~min}$, with an average time of $24.8 \mathrm{~min}$. The temperature corresponding to the minimal final time $(20 \mathrm{~min})$ of the thermal dosage administration $\left(\mathrm{T}_{20}\right)$ was not below $33.7^{\circ} \mathrm{C}$. Accordingly, these values were able to assure heat transfer between the samples and the skin in normal application products. This good behavior confirmed that Venezuelan kaolins exhibit adequate thermal dosage performance and qualify them for semisolid mud packs formulations by $50 \%$ water contents for pelotherapeutic uses.

\section{Conclusions}

Eight samples were selected from Venezuelan kaolin deposits to evaluate their sustainability for application as therapeutic muds. In general, the samples showed suitable colloidal behavior and consistent thermal dosage performance. Three samples (VE3, VE6, VE9) were particularly interesting because of their high purity ( $>92 \%$ kaolinite), viscosities ( $>1 \mathrm{~Pa} \cdot \mathrm{s})$, adequate thermal properties (specific heat in the $2.6-3 \mathrm{~J} / \mathrm{K} \cdot \mathrm{g}$ range, and $>32{ }^{\circ} \mathrm{C}$ temperature during typical minimum topical application time), and $\mathrm{pH}$ range (4.4-5.9) in the optimal skin $\mathrm{pH}$ values for topical application. Samples showed small variations in zeta potential related to the tendency to flocculation and the high viscosities measured in the samples. There was a positive correlation between $\mathrm{HI}$ and the experimental specific heat values and negative correlation between $\mathrm{HI}$ and $\mathrm{Ca}^{2+}$ and $\mathrm{Mg}^{2+}$ contents. Therefore, kaolinite crystallinity influences the thermal behavior and desorption of ions on the kaolinite surface.

Author Contributions: Conceptualization, C.V.; Field-trips and geology, W.M.; Methodology, literature review, interpretation or materials data, discussion, A.C.H., M.E.A., F.G.-V., R.S.-E.; Writing-original draft preparation, A.C.H., M.E.A.; Supervision and writing-review, G.G., A.L.-G., C.V.; Editing, A.L.-G.

Funding: This research was funded by Spanish MINECO project (CGL2016-80833R), Junta de Andalucía (group CTS-946) and a grant from the Academic mobility program between institutions (Postgraduate Ibero-American University Association, AUIP).

Acknowledgments: The authors are grateful to the laboratory technicians of the IACT.

Conflicts of Interest: The authors declare no conflict of interest. The funders had no role in the design of the study; in the collection, analyses, or interpretation of data; in the writing of the manuscript, or in the decision to publish the results.

\section{References}

1. Summa, V.; Tateo, F. The use of pelitic raw materials in termal centres: Mineralogy, geochemistry, grain size and leaching tests. Examples from Lucania area (Southern Italy). Appl. Clay Sci. 1998, 12, $403-417$. [CrossRef] 
2. Viseras, C.; López-Galindo, A. Pharmaceutical applications of some Spanish clays (sepiolite, palygorskite, bentonite): Some preformulation studies. Appl. Clay Sci. 1999, 14, 69-82. [CrossRef]

3. Cara, S.; Carcangiu, G.; Padalino, G.; Palomba, M.; Tamanini, M. The bentonites in pelotherapy: Thermal properties of clay pastes from Sardinia (Italy). Appl. Clay Sci. 2000, 16, 125-132. [CrossRef]

4. Carretero, M.I. Clay minerals and their beneficial effects upon human health: A review. Appl. Clay Sci. 2002, 21, 155-163. [CrossRef]

5. Veniale, F.; Barberis, E.; Carcangiu, G.; Morandi, N.; Setti, M.; Tamanini, M.; Tessier, D. Formulation of muds for pelotherapy: Effects of "maturation" by different mineral waters. Appl. Clay Sci. 2004, 25, 135-148. [CrossRef]

6. Carretero, M.I.; Gomes, C.S.F.; Tateo, F. Clays and human health. In Handbook of Clay Science; Bergaya, F., Theng, B.K.G., Lagaly, G., Eds.; Elsevier: Amsterdam, The Netherlands, 2006; Volume 1, pp. 717-741.

7. Carretero, I.; Pozo, M. Mineralogia Applicada: Salud y Medio Ambiente; Paraninfo: Madrid, Spain, 2007; 424p.

8. Tateo, F.; Summa, V. Element mobility in clays for healing use. Appl. Clay Sci. 2007, 36, 64-76. [CrossRef]

9. Veniale, F.; Bettero, A.; Jobstraibizer, P.; Setti, M. Thermal muds: Perspectives of innovations. Appl. Clay Sci. 2007, 36, 141-147. [CrossRef]

10. Viseras, C.; Aguzzi, C.; Cerezo, P.; López-Galindo, A. Uses of clay minerals in semisolid health care and therapeutic products. Appl. Clay Sci. 2007, 36, 37-50. [CrossRef]

11. Dolmaa, G.; Tserenpil, S.; Ugtakhbayar, O.; Shevchenko, S.G.; Kliba, L.V.; Voronkov, M.G. Characterization and organic compounds in peloids from Mongolia. Proc. Mong. Acad. Sci. 2009, 49, 3-21. [CrossRef]

12. Carretero, M.I.; Pozo, M.; Martín-Rubí, J.A.; Pozo, E.; Maraver, F. Mobility of elements in interaction between artificial sweat and peloids used in Spanish spa. Appl. Clay Sci. 2010, 48, 506-515. [CrossRef]

13. Karakaya, M.; Karakaya, N.; Sarioglan, S.; Koral, M. Some properties of thermal muds of some spas in Turkey. Appl. Clay Sci. 2010, 48, 531-537. [CrossRef]

14. Matike, D.M.E.; Ekosse, G.I.E.; Ngole, V.M. Physico-chemical properties of clayey soils used traditionally for cosmetics in Eastern Cape, South Africa. Int. J. Phys. Sci. 2011, 6, 7557-7566.

15. Sánchez-Espejo, R.; Cerezo, P.; Aguzzi, C.; López-Galindo, A.; Machado, J.; Viseras, C. Physicochemical and in vitro cation release relevance of therapeutic muds "maturation". Appl. Clay Sci. 2015, 116, 1-7. [CrossRef]

16. Lagaly, G. Principles of flow of kaolin and bentonite dispersions. Appl. Clay Sci. 1989, 4, 105-123. [CrossRef]

17. Bundy, W.M.; Ishley, J.N. Kaolin in paper filling and coating. Appl. Clay Sci. 1991, 5, 397-420. [CrossRef]

18. Murray, H.H.; Keller, W.D. Kaolins, kaolins, kaolins. In Kaolin Genesis and Utilization; Murray, H.H., Bundy, W., Harvey, C., Eds.; The Clay Minerals Society: Boulder, CO, USA, 1993; Spec. Pub.1; pp. 1-24.

19. De Bernardi, M.; Pedrinazzi, G.M. Azioni biologiche dei fanghi termali. In Atti Convegno Argille Curative; Veniale, F., Ed.; Gruppo Italiano AIPEA: Pavia, Italy, 1996; pp. 17-24.

20. Yuan, J.; Murray, H.H. The importance of crystal morphology on the viscosity of concentrated suspensions of kaolins. Appl. Clay Sci. 1997, 12, 209-219. [CrossRef]

21. Minguzzi, N.; Morandi, N.; Tagnin, S.; Tateo, F. Le argille curative in uso negli stabilimenti termali Emiliano-Romagnoli: Verifica della composizione e delle proprieta. In Argille Per Fanghi Peloidi Termali E Per Trattamenti Dermatologici E Cosmetici; Veniale, F., Ed.; Symp. Gruppo Ital. AIPEA: Montecatini Terme, Italy, 1999; Volume XLII, pp. 287-298.

22. Veniale, F. Argille Curative Per Fanghi Peloidi Termali E Per Trattamienti Dermatologici E Cosmetici; Symp. Gruppo Ital. AIPEA: Montecatini Terme, Italy, 1999; Volume XLII, pp. 261-335.

23. Millman, N. Some factors that influence the viscosity of paper coating compositions. Tappi 1964, 47, 168A-175A.

24. Ferrand, T.; Yvon, J. Thermal properties of clay pastes for pelotherapy. Appl. Clay Sci. 2000, 6, 751-760. [CrossRef]

25. Legido, J.L.; Mourelle, M.L. Investigaciones En El Ámbito Iberoamericano Sobre Peloides Termales; Universidad de Vigo: Vigo, Spain, 2008; p. 308.

26. Armijo, F.; Maraver, F.; Pozo, M.; Carretero, M.I.; Armijo, O.; Fernández-Torán, M.A.; Fernández-González, M.V.; Corvillo, I. Thermal behaviour of clays and clay-water mixtures for pelotherapy. Appl. Clay Sci. 2016, 126, 50-56. [CrossRef]

27. Awad, M.E.; López-Galindo, A.; Setti, M.; El-Rahmany, M.M.; Iborra, C.V. Kaolinite in pharmaceutics and biomedicine. Int. J. Pharm. 2017, 533, 34-48. [CrossRef] 
28. Ramasamy, S.; Hussin, K.; Abdullah, M.M.A.; Ruzaidi, C.M.; Binhussain, M.; Sandu, A.V. Effect of solid/liquid ratio on mechanical properties of kaolin coated teak wood via geopolymer technology. App. Mech. Mater. 2015, 754, 708-713. [CrossRef]

29. Awad, M.E.; López-Galindo, A.; Sánchez-Espejo, R.; El-Rahmany, M.M.; Iborra, C.V. Thermal properties of some Egyptian kaolin pastes for pelotherapeutic applications: Influence of particle geometry on thermal dosage release. Appl. Clay Sci. 2018, 160, 193-200. [CrossRef]

30. Awad, M.E.; López-Galindo, A.; Sánchez-Espejo, R.; Sainz-Díaz, C.I.; El-Rahmany, M.M.; Viseras, C. Crystallite size as a function of kaolinite structural order-disorder and kaolin chemical variability: Sedimentological implication. Appl. Clay Sci. 2018, 162, 261-267. [CrossRef]

31. Hernández, A.C.; Sánchez-Espejo, R.; Meléndez, W.; González, G.; López-Galindo, A.; Viseras, C. Characterization of Venezuelan kaolins as health care ingredients. Appl. Clay Sci. 2019, 175, 30-39. [CrossRef]

32. Williams, D.J.A.; Williams, K.P. Electrophoresis and zeta potential of kaolinite. J. Colloid Interface Sci. 1977, 65, 79-87. [CrossRef]

33. Schott, H. Reología. In Remington. Farmacia; Gennaro, A.R., Ed.; Editorial Médica Panamericana: Buenos Aires, Argentina, 1995; Volume I, pp. 426-455.

34. Conceição, S.; Santos, N.F.; Velho, J.; Ferreira, J.M.F. Properties of paper coated with kaolin: The influence of the rheological modifier. Appl. Clay Sci. 2005, 30, 165-173. [CrossRef]

35. De Azerêdo, A.F.; Azeredo, G.; Carneiro, A.M. Study of rheological parameters of lime-metakaolin paste made of kaolin wastes and lime paste. Key Eng. Mater. 2015, 668, 419-432. [CrossRef]

36. Awad, M.E.; López-Galindo, A.; El Rahmany, M.M.; El-Desoky, H.M.; Viseras, C. Characterization of Egyptian kaolins for health-care uses. Appl. Clay Sci. 2017, 135, 176-189. [CrossRef]

37. Qiu, X.; Liu, Y.; Alshameri, A.; Zhu, X.; Yan, C. Viscosity of kaolin slurries: Effects of dispersant and urea-intercalation. J. Wuhan Univ. Technol.-Mater. Sci. Ed. 2017, 32, 51-57. [CrossRef]

38. Aguzzi, C.; Sánchez-Espejo, R.; Cerezo, P.; Machado, J.; Bonferoni, M.C.; Rossi, S.; Salcedo, I.; Viseras, C. Networking and rheology of concentrated clay suspensions "matured" in mineral medicinal water. Int. J. Pharm. 2013, 453, 473-479. [CrossRef]

39. Modabberi, S.; Namayandeh, A.; López-Galindo, A.; Viseras, C.; Setti, M.; Ranjbaran, M. Characterization of Iranian bentonites to be used as pharmaceutical materials. Appl. Clay Sci. 2015, 116, 193-201. [CrossRef]

40. Sánchez-Espejo, R.; Aguzzi, C.; Cerezo, P.; Salcedo, I.; López-Galindo, A.; Viseras, C. Folk pharmaceutical formulations in western Mediterranean: Identification and safety of clays used in pelotherapy. J. Ethnopharmacol. 2014, 155, 810-814. [CrossRef] [PubMed]

41. Conde-Pumpido, R.; Ferrón, J.J.; Campillo, G. Influence of granulometric factors on the rheology of kaolins of Galicia, Spain. Appl. Clay Sci. 1988, 3, 177-185. [CrossRef]

42. Wierenga, A.M.; Lenstra, T.A.J.; Philipse, A.P. Aqueous dispersions of colloidal gibbsite platelets: Synthesis, characterisation and intrinsic viscosity measurements. Colloids Surf. Physicochem. Eng. Asp. 1998, 134, 359-371. [CrossRef]

43. Lambers, H.; Piessens, S.; Bloem, A.; Pronk, H.; Finkel, P. Natural skin surface pH is on average below 5, which is beneficial for its resident flora. Int. J. Cosm. Sci. 2006, 28, 359-370. [CrossRef]

44. Fluhr, J.W.; Elias, P.M. Stratum corneum pH: Formation and function of the 'acid mantle'. Exog. Dermatol. 2002, 1, 163-175. [CrossRef]

45. Driscoll, C.T.; Postek, K.M. The chemistry of aluminum in surface waters. In The Environmental Chemistry of Aluminum, 2nd ed.; Sposito, G., Ed.; Lewis Publishers: New York, NY, USA, 1996; pp. 363-418.

46. Krewski, D.; Yokel, R.A.; Nieboer, E.; Borchelt, D.; Cohen, J.; Harry, J.; Kacew, S.; Lindsay, J.; Mahfouz, A.M.; Rondeau, V. Human health risk assessment for aluminium, aluminium oxide, and aluminium hydroxide. J. Toxicol. Environ. Health B 2007, 10, 1-269. [CrossRef]

47. Becker, L.C.; Boyer, I.; Bergfeld, W.F.; Belsito, D.V.; Hill, R.A.; Klaassen, C.D.; Liebler, D.C.; Marks, J.G., Jr.; Shank, R.C.; Slaga, T.J.; et al. Safety assessment of alumina and aluminum hydroxide as used in Cosmetics. Int. J. Toxicol. 2016, 35, 16S-33S. [CrossRef]

48. Yukselen, Y.; Kaya, A. A study of factors affecting on the zeta potential of kaolinite and quartz powder. Environ. Earth Sci. 2011, 62, 697-705. [CrossRef]

49. Qiu, X.; Lei, X.; Alshameri, A.; Wang, H.; Yan, C. Comparison of the physicochemical properties and mineralogy of Chinese (Beihai) and Brazilian kaolin. Ceram. Int. 2014, 40, 5397-5405. [CrossRef] 
50. Ndlovu, B.; Farrokhpay, S.; Forbes, E.; Bradshaw, D. Characterisation of kaolinite colloidal and flow behaviour via crystallinity measurements. Powder Technol. 2015, 269, 505-512. [CrossRef]

51. Usuga-Manco, L.M.; López-Valdivieso, A.; Bustamante-Rúa, M.O. Hydrophobicity study of kaolinite from La Unión, Antioquia. TecnoLógicas 2015, 18, 71-81. [CrossRef]

52. Au, P.I.; Leong, Y.K. Surface chemistry and rheology of slurries of kaolinite and montmorillonite from different sources. Kona Powder Part. J. 2016, 33, 17-32. [CrossRef]

53. Adekola, F.; Fédoroff, M.; Geckeis, H.; Kupcik, T.; Lefèvre, G.; Lützenkirchen, J.; Plaschke, M.; Preocanin, T.; Rabung, T.; Schild, D. Characterization of acid-base properties of two gibbsite samples in the context of literature results. J. Coll. Interface Sci. 2011, 354, 306-317. [CrossRef] [PubMed]

54. Cunha, F.O.; Torem, M.L.; D'Abreu, J.C. On the fundamentals of kaolin rheology applied to the paper industry. Miner. Eng. 2006, 19, 1462-1464. [CrossRef]

55. Du, J.; Morris, G.; Pushkarova, R.A.; Smart, R.S.C. Effect of surface structure of kaolinite on aggregation, settling rate, and bed density. Langmuir 2010, 26, 13227-13235. [CrossRef] [PubMed]

56. Yukselen, Y.; Kaya, A. Zeta potential of kaolinite in the presence of alkali, alkaline earth and hydrolyzable metal ions. Waterairand Soil Pollut. 2003, 145, 155-168. [CrossRef]

57. Bolland, M.D.A.; Posner, A.M.; Quirk, J.P. pH-independent and pH-dependent surface charges on kaolinite. Clays Clay Miner. 1980, 28, 412-418. [CrossRef]

58. Atesok, G.; Somasundaran, P.; Morgan, L.J. Adsorption properties of $\mathrm{Ca}^{2+}$ on Na-kaolinite and its effect on flocculation using polyacrylamides. Colloids Surf. 1988, 32, 127-138. [CrossRef]

59. Legido, J.L.; Medina, C.; Mourelle, M.L.; Carretero, M.I.; Pozo, M. Comparative study of the cooling rates of bentonite, sepiolite and common clays for their use in pelotherapy. Appl. Clay Sci. 2007, 36, 148-160. [CrossRef]

(C) 2019 by the authors. Licensee MDPI, Basel, Switzerland. This article is an open access article distributed under the terms and conditions of the Creative Commons Attribution (CC BY) license (http://creativecommons.org/licenses/by/4.0/). 